\title{
TOXICOLOGICAL EFFECT OF INHALED MOSQUITO INCENSE STICKS SMOKE ON THE HISTOLOGY AND BIOCHEMICAL RESPONSES IN EXPERIMENTAL RATS
}

\author{
${ }^{* 1}$ Nafiu, S. A; ${ }^{2}$ Dahiru, M. M; ${ }^{3}$ Rabiu, D. H. and ${ }^{4}$ Mohammed, J. M \\ ${ }^{1}$ Department of Science Laboratory Technology, Kano State Polytechnic, Kano \\ ${ }^{2}$ Department of Science Laboratory Technology, Federal Polytechnic, Bauchi, \\ ${ }^{3}$ Department of Biology, Federal College of Education (Technical) Bichi, Kano State \\ ${ }^{4}$ Department of General Studies, College of Administrative and Business Studies, Potiskum, Yobe State. \\ ${ }^{*}$ Correspondence author: nafiune.sn@gmail.com +23407030918094
}

\begin{abstract}
This study was carried out to investigate the toxicological effects of four brands of mosquito incense stick smoke (DR insecticide stick (AS-1987), Incense upgraded formula (BM-102), Fragrance (B3-254) and Citronella (A7-435) on selected biochemical and histological profile of male albino wistar rats. Fifteen (15) wistar rats with mean weight $(174.6 \pm 0.91 \mathrm{~g})$ were randomly divided into five (5) groups. Group I were considered as negative control while group II, III, IV and V were challenged with the brands of mosquito incense stick smoke for 8 hours daily by inhalation for 21 days. Laboratory investigations were carried out using standard protocols. It was observed that the activities of the liver enzymes (Alanine Aminotransferase (ALT), Aspartate Aminotransferase (AST) and Alkaline Phosphatase (ALP) increased significantly $(\mathrm{p}<0.05)$ in all the experimental rats when compared with the control. The histopathological alterations examined in the liver tissues of the experimental rats during the study period include mild necrosis, mild degeneration of hepatocytes and cellular infiltration from group III, IV and V respectively. Lung tissues of the challenged rats of group II, III and V revealed mild cellular infilterations around alveolar septa, hyperplasia and bronchiolar epithelial wall degeneration respectively. Kidney tissues revealed glomeruli distortion, mild haemorrhage and renal damage from group III and IV respectively. The alterations examined in the liver, kidney and lung tissues of the experiment rats were period dependent but independent of mosquito sticks brands which inferred that continuous exposure to mosquito stick by inhalation has the potentials to facilitate different pathological effect with multiple organs toxicity in the long run.
\end{abstract}

Keywords: Histopathology, liver enzymes, incense stick based-insecticides, albino wistar rats

\section{INTRODUCTION}

Mosquito sticks are slow-burning devices which emit smoke containing one or more insecticides for hours. They are applied in close proximity to persons requiring protection against mosquitoes in order to prevent malaria, a disease of wide distribution (Abdullah et al., 2017). The scourge of malaria had led citizens in low income communities to adopt the use of mosquito stick or coil to control the mosquito populations around residential areas because they are cheap and readily available (El-Demerdash, 2011).

The activities of mosquito stick have been demonstrated against Aedes, Anopheles and Mansonia (Lawrence and Croft, 2004). The health implications of burning one mosquito stick is equivalent to the release of the same amount of particulate matter as burning 75 to 137 cigarettes and emitting formaldehyde equivalent to 51 cigarettes (Chen et al., 2008). The gas phase of mosquito stick smoke have been reported to contain carbonyl compounds (formaldehyde and acetaldehyde) with properties that can produce strong irritating effects on the upper respiratory tract (Garba et al., 2007).

Histopathological investigations have demonstrated that mosquito smoke leads to focal inflammation of the tracheal epithelium, metaplasia of the epithelial cells and morphological alteration of the alveolar macrophages (Garba et al., 2007 and Fetoui et al., 2010).

Moquito coil smoke is considered as a potent air pollutant in indoor environment and prolong exposure to the smoke could alter blood biochemical parameters in mice (Idowu et al., 2016). For instance, exposure of the albino rats to pyrethroid-based insecticides smoke has been reported to cause significant increase in the liver enzyme (AST, ALT and ALP) activities with a decrease in the levels of total protein and serum albumin(Ugwu et al., 2016). According to Abubakar and Hassan (2007), liver enzymes such as AST, ALT and ALP activities were significantly increased due to exposure to different brands of mosquito coil. Ugwu et al. (2016) reported 
increased in the levels of urea and creatinine in rats exposed to mosquito smoke. In view of the forgoing this research aimed at evaluating the toxicity profile of four new brands of mosquito incense sticks smoke on the histology and biochemical responses in experimental rats.

\section{MATERIALS AND METHODS}

Table 1: Brands of Mosquito incense Sticks Used for the Research

\begin{tabular}{llc}
\hline Brand & Country & Active ingredient \\
\hline $\begin{array}{l}\text { DR insecticide stick } \\
\text { (AS-1987) }\end{array}$ & Nigeria & Meperfluthrin $0.2 \%$ \\
$\begin{array}{l}\text { Incense upgraded formula } \\
(B M-102)\end{array}$ & China & Rich-d-transllethrin $0.25 \%$ \\
$\begin{array}{l}\text { Citronella (A7-435) } \\
\text { Fragrance (B3-254) }\end{array}$ & India & Citronella \\
\hline
\end{tabular}

\section{Experimental Animals}

A total of fifteen (15) adult male albino rats with mean weight of 174.6 $\pm 0.91 \mathrm{~g}$ were procured from animal room of Biological Science Department, Bayero University Kano and were kept in animal cage with a dimension of $(40.20 \mathrm{~cm}$ by $23.40 \mathrm{~cm}$ by $18 \mathrm{~cm}$ ) at room temperate of $\pm 28.7^{\circ} \mathrm{C}$ and relative humidity of $<30 \%$ with a 12 hour light/dark cycle. The animals were acclimatized on standard pelletized grower feed and allowed access to free drinking water for one week as adopted by Muhammed and Yakasai (2017).

\section{Determination of Physical Changes in Animals}

The weight of experimental and control rats were taken before and after the study for any Physical and behavioral changes such as; body weight changes, loss of hairs, coughing and sneezing as adopted by Muhammed and Yakasai (2017).

Experimental Design and Exposure to Mosquito Incense Sticks Smoke

The experimental rats were randomly grouped into five (5) groups that is $\mathrm{I}-\mathrm{V}$ of three rats each. They were kept in undisturbed cages of size $40.20 \mathrm{~cm}$ by $23.40 \mathrm{~cm}$ by $18 \mathrm{~cm}$ with 5 meters distance to each other and a cross ventilation for 8 hours daily for 21 days. The control group was not challenged to any mosquito stick smoke inhalation. Groups II-V was used for the sub chronic investigation as adopted by Garba et al. (2007). At the end of the exposure period, the experimental rats were sacrificed by humane killing as described by Organization for Economic Co-operation and Development (OECD) (2011).

\section{Histopathological Investigation}

The biopsies of rat's tissues (lung, liver and kidney) were carried out at Histopathology Laboratory, Aminu Kano Teaching Hospital, Kano-Nigeria using the method described by Ochei and Kolhatkar (2007). The experimental rats' tissues were euthanized with $40 \%$ ethyl alcohol before individually excising their lungs, liver and kidney for histopathological investigation. The tissues were fixed with $10 \%$ formal saline dehydrated with

\section{Test Materials}

Four (4) new brands of mosquito incense sticks were procured from registered store at Sabongari market in Kano state, Nigeria. The country of origin NAFDAC number, Batch number and the list of active ingredient were obtained from the package. Measurement was obtained from the mosquito incense sticks such as diameter $3.5 \mathrm{~cm}, 30 \mathrm{~cm}$ for length and $1.6 \mathrm{~g}$ for weight. ascending grade of alcohol, cleared with toluene, infiltrated with molten paraffin wax. Microtome sections $(5 \mu \mathrm{m})$ of the tissue were stained with Haematoxylin and Eosin stains and examined with microscope (LEICA DM 750 model) and photomicrographed with HD camera (LEICA ICE 50 model).

\section{Biochemical Analyses}

At the end of the exposure period of 21 days, the experimental rats were put to sleep with chloroform and prominent jugular vein was incised as adopted by Nafiu et al. (2020).Blood samples were collected from challenged and control group with heparinized plastic syringe, fitted with 21 gauge hypodermic needle. The blood sample was collected in lithium heparin bottles and EDTA bottles for biochemical analysis (The aspartate aminotransferase (AST), Alkaline phosphatase (ALP) and alanine aminotransferase (ALT) activities). ALT, ALP, AST were determined at Biochemistry Laboratory, Bayero University Kano, using Randox kits as adopted by Ezenwaji et al. (2013).

\section{Statistical Analysis}

Statistical analysis was conducted using SPSS (Version 23.0). Data from the 3 replicates of the experiment was subjected to one-way Analysis of Variances of (ANOVA). Treatment means was separated using DMRT at 5\% probability level. Probability level of less than $5 \%(\mathrm{p}<0.05)$ was considered significant.

\section{RESULTS}

Toxicological implication of inhaled mosquito incense sticks smoke on Mean Body Weight

During the study period, there was significant difference $(p<0.05)$ between the mean body weight of the rats challenged with group III mosquito incense sticks smoke when compared to the control group which recorded increase in weight (Table 1). With regards to the physical and behavioural changes at the beginning of the treatment, the experimental rats were examined to be active, with normal feeding on the first day. However, after 
2 weeks exposure feeding habit decreased with regular sneezing, coughing and body weakness which continued for the remaining period of exposure. None of the above behavioural changes was observed in the control group.

Table 1: Mean Weight of Experimental Rats before and after Exposure with Mosquito Incense Sticks Smoke

\begin{tabular}{lccc}
\hline Group ID & Mean weight before exposure & Mean weight after exposure & $\begin{array}{c}\text { Mean weight gain/loss } \\
\text { after exposure }\end{array}$ \\
\hline $\begin{array}{l}\text { Group 1 } \\
\text { (Contol) }\end{array}$ & $282.5 \pm 2.46$ & $293.32 \pm 2.64$ & $10.8 \pm 1.81$ \\
$\begin{array}{l}\text { Group II } \\
\text { (DR) }\end{array}$ & $166.40 \pm 1.50$ & $147.50 \pm 3.64$ & $-18.9 \pm 0.31$ \\
$\begin{array}{l}\text { Group III } \\
\text { (IGP) }\end{array}$ & $155.36 \pm 3.00$ & $133.18 \pm 1.92$ & $-22.8 \pm 0.52$ \\
$\begin{array}{l}\text { Group IV } \\
\text { (CIT) }\end{array}$ & $141.50 \pm 1.85$ & $120.66 \pm 1.33$ & $-20.5 \pm 1.43$ \\
$\begin{array}{l}\text { Group V } \\
\text { (FRG) }\end{array}$ & $127.13 \pm 1.11$ & $113.38 \pm 1.46$ & $-14.13 \pm 0.81$ \\
\hline
\end{tabular}

Group I= Control, II= DR insecticide stick (AS-1987), III =Incense upgraded formula (BM-102), IV= Fragrance (B3-254), V= Citronella (A7-435)

\section{Biochemical Analysis}

The mean liver AST of the experimental rats increased at 21 days when challenged to different brands of mosquito incense sticks smoke (Table 2). Lowest activity was obtained in the control group of $32.70 \pm 1.02 \mathrm{U} / \mathrm{L}$ and the highest of $45.40 \pm$ $0.71 \mathrm{U} / \mathrm{L}$ was obtained in group V. The AST activity between control and treatment did not differ significantly $(\mathrm{P}>0.05)$.

The activity ALT was highest $(56.41 \pm 0.97 \mathrm{U} / \mathrm{L})$ in experimental rats challenged in group III incense stick smoke (Table 2). The lowest values were observed at Group II, IV, and Group V which were $43.34 \pm 1.45 \mathrm{U} / \mathrm{L}, \quad 49.00 \pm 1.48 \mathrm{U} / \mathrm{L}$ and $48.70 \pm 8.37 \mathrm{U} / \mathrm{L}$ respectively as against the control value of $42.05 \pm 0.43 \mathrm{U} / \mathrm{L}$. Statistically there was no significant difference between the groups $(\mathrm{P}>0.05)$.

The activity of ALP also show no mosquito stick dependent in which the highest value obtained at Group III of $29.29 \pm 1.81 \mathrm{u} / \mathrm{l}$ followed by the Group II with $23.20 \pm 1.83 \mathrm{u} / 1$ and Group IV $22.24 \pm 1.24 \mathrm{u} / \mathrm{l}$ respectively as against the lowest value from the control group of $21.70 \pm 0.62 \mathrm{u} / \mathrm{l}$. The value obtained differed significantly $(\mathrm{P}<0.05)$.

Table 2: Mean Concentrations of Biochemical Indices of Experimental Rats Exposed to mosquito sticks Smoke

\begin{tabular}{llll}
\hline Group/parameters & AST $(\mathrm{U} / \mathrm{L})$ & ALT $(\mathrm{U} / \mathrm{L})$ & ALP $(\mathrm{U} / \mathrm{L})$ \\
\hline GROUP I & $42.05 \pm 0.43^{\mathrm{a}}$ & $32.70 \pm 1.02^{\mathrm{a}}$ & $21.70 \pm 0.62^{\mathrm{a}}$ \\
GROUP II & $43.34 \pm 1.45^{\mathrm{a}}$ & $33.70 \pm 0.11^{\mathrm{a}}$ & $23.20 \pm 1.83^{\mathrm{a}}$ \\
GROUP III & $56.41 \pm 0.97^{\mathrm{a}}$ & $38.56 \pm 1.07^{\mathrm{a}}$ & $23.29 \pm 1.81^{\mathrm{a}}$ \\
GROUP IV & $49.00 \pm 1.48^{\mathrm{a}}$ & $42.19 \pm 0.35^{\mathrm{a}}$ & $22.24 \pm 1.24^{\mathrm{a}}$ \\
GROUP V & $48.70 \pm 8.37^{\mathrm{a}}$ & $45.40 \pm 0.71^{\mathrm{a}}$ & $26.10 \pm 0.41^{\mathrm{d}}$ \\
\hline
\end{tabular}

Means with same superscripts in a column did not differ significantly $(\mathrm{p}>0.05)$.

Sub-chronic toxicity revealed treatment-related tissue alterations in the experimental rats challenged with brands of mosquito incense sticks smoke. Liver tissue had normal appearance with normal hepatocytes, morphology, vacuolation and hepatic cord arrangement in the control samples without any discernible changes (Plate 1a). Histological analysis of the rat's liver challenged with mosquito incense sticks smoke for 21 days showed mild necrosis (plate 1b), degeneration of hepatocytes (plate 1c) and cellular infiltration (plate 1d) from group III, IV and V respectively. 

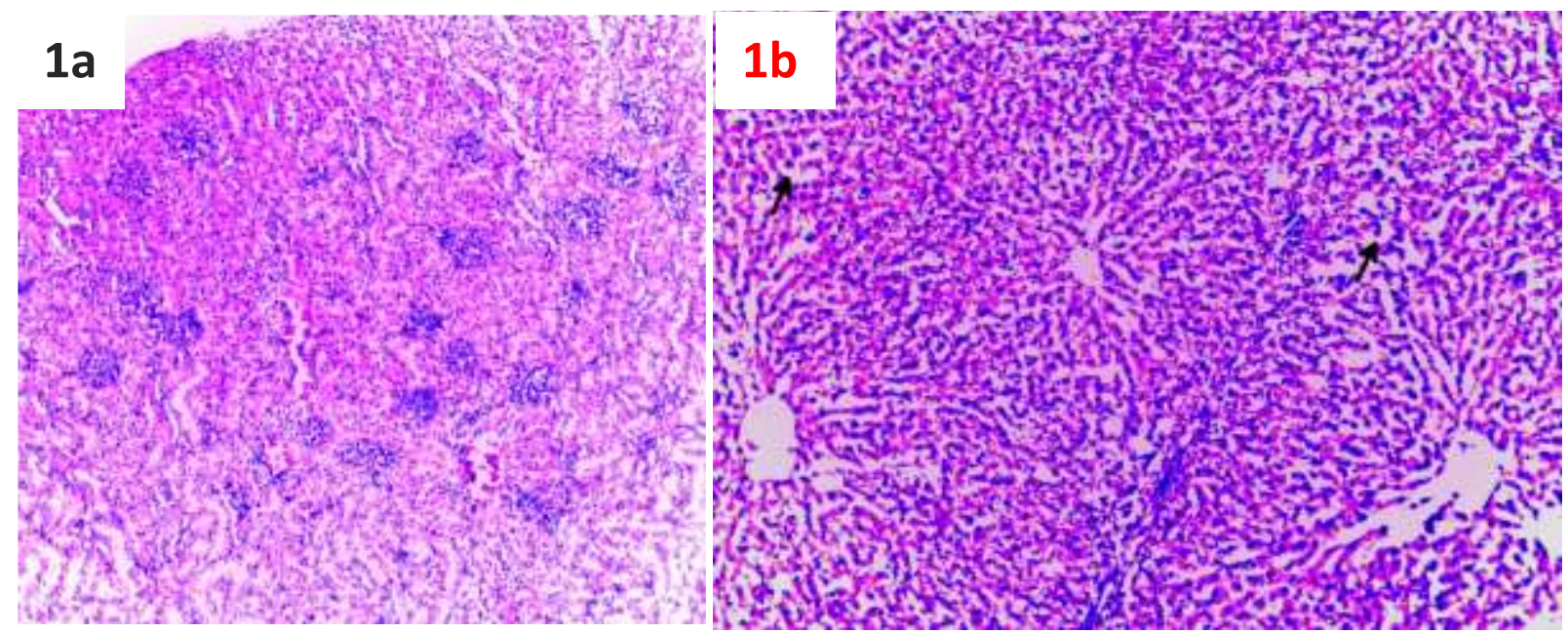

Plate 1a Photomicrograph of normal liver tissue structure of wistar rat (H \& E mag x 100)

Plate 1b Photomicrograph of wistar rat liver tissue challenged with group III mosquito incense stick smoke showing areas of mild necrosis (H \& E mag x 100)

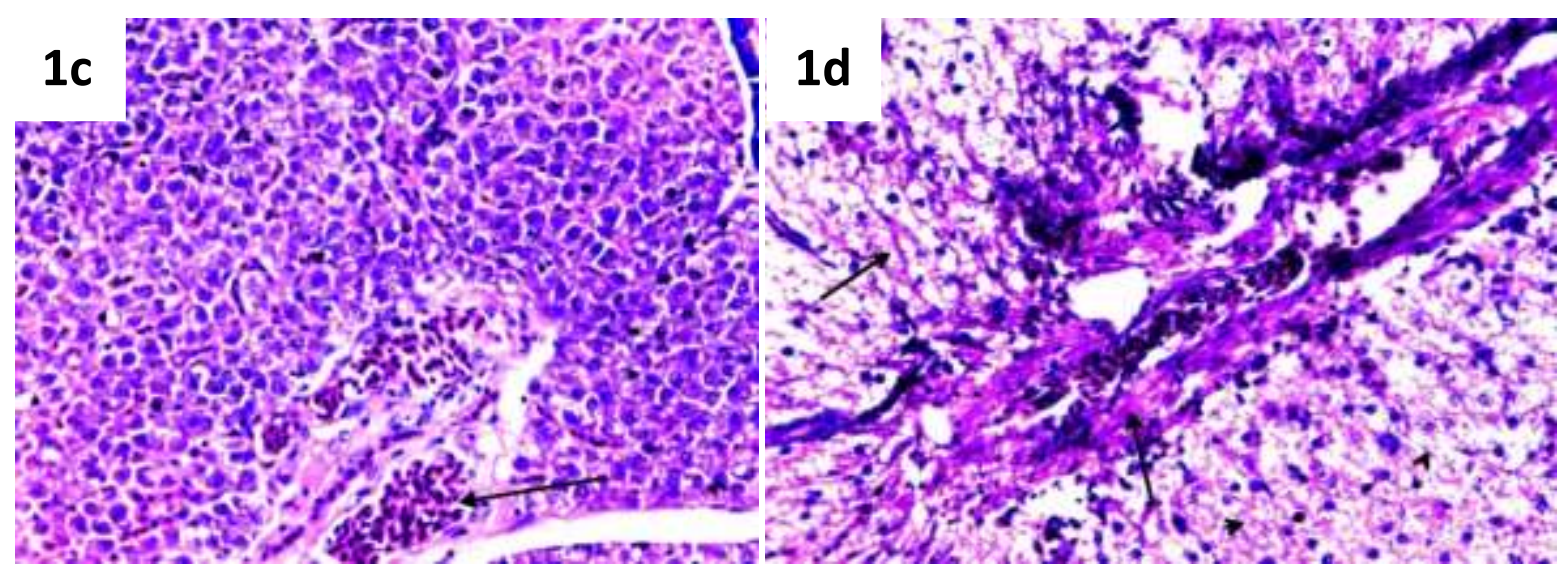

Plate 1c: Photomicrograph of wistar rat liver tissue challenged with group IV mosquito incense stick smoke showing areas of degeneration of hepatocytes (H \& E mag x 100)

Plate 1d: Photomicrograph of wistar rat liver tissue challenged with group V mosquito incense stick smoke showing areas of cellular infilteration (H \& E mag x 100).

Photomicrograph section of control rat's pulmonary tissues showed normal alveolar sacs architecture without any discernible lesions (plate 2a). Nevertheless, mosquito sticks smoke inhaled by experimental rats from group II, III and V revealed inflammatory cells disruption around alveolar septa (plate 2b), hyperplasia (plate 2c) and degeneration of bronchiolar epithelial wall (plate 2d) respectively. 


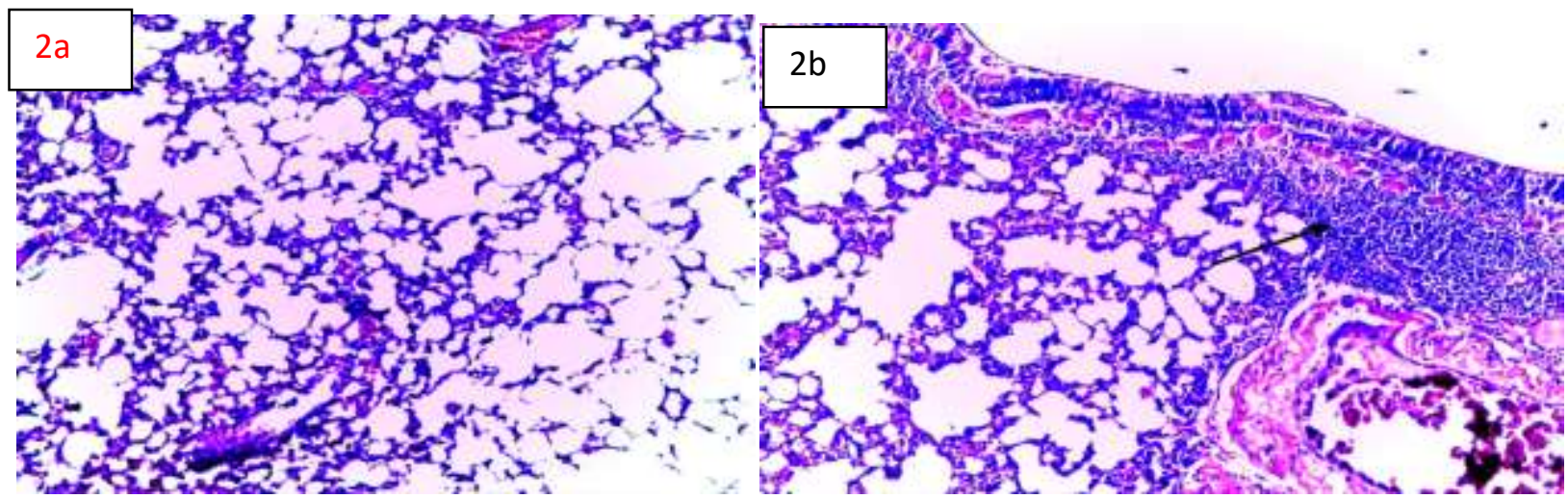

Plate 2a Photomicrograph section of wistar rat lung showing normal lung tissue alveolar sacs architecture without any discernible lesions

Plate $2 b$ Photomicrograph section of wistar rat lung challenged with group II mosquito incense stick smoke showing areas of inflammatory cells disruption around alveolar septa (H \& E mag x 100)

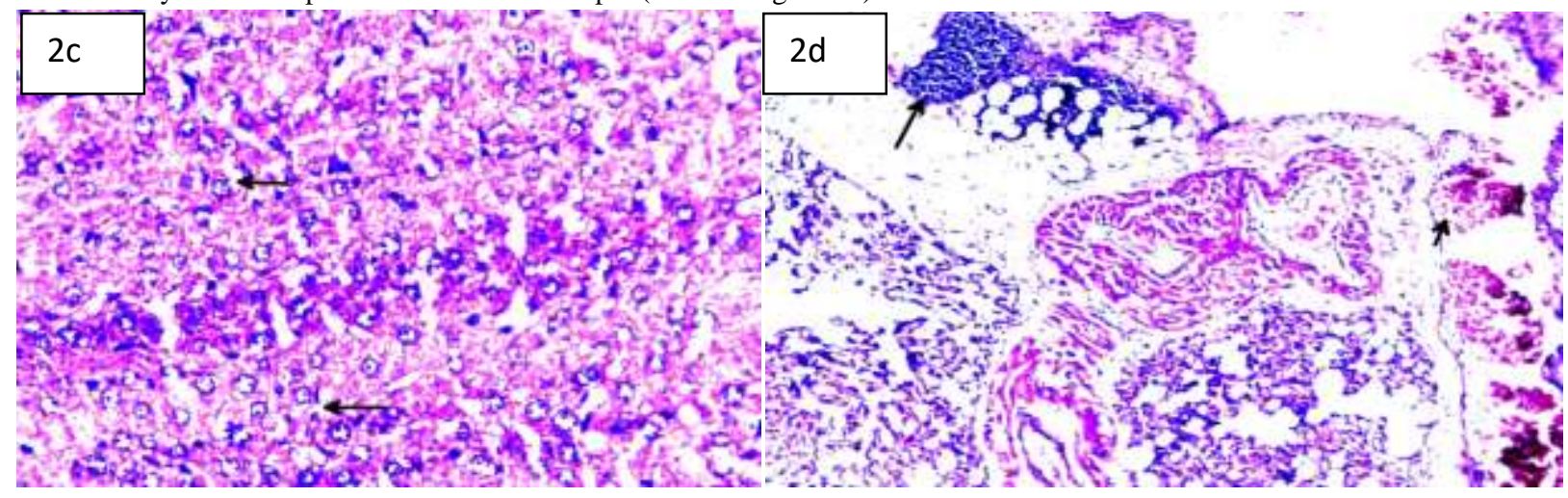

Plate 2c Photomicrograph section of wistar rat lung challenged with group III mosquito incense stick smoke showing areas of hyperplasia (H \& E mag x 100)

Plate $2 \mathrm{~d}$ Photomicrograph section of wistar rat lung challenged with group V mosquito incense stick smoke showing areas of degeneration of bronchiolar epithelial wall (H \& E mag x 100)

Photomicrograph section of wistar rat kidney challenged with different groups of insecticides mosquito incense stick smoke for 21 days revealed normal tissue architecture without any visible lesion in the control samples (Plate 3a) when compared with experimental groups. Glomeruli distortion (Plate 3b) and mild haemorrhage and renal damage (Plate 3c) were the significant changes examined in the kidney tissues of group III and IV rats. Statistically there is no significant difference $(\mathrm{P}>0.05)$ between experimental samples. 

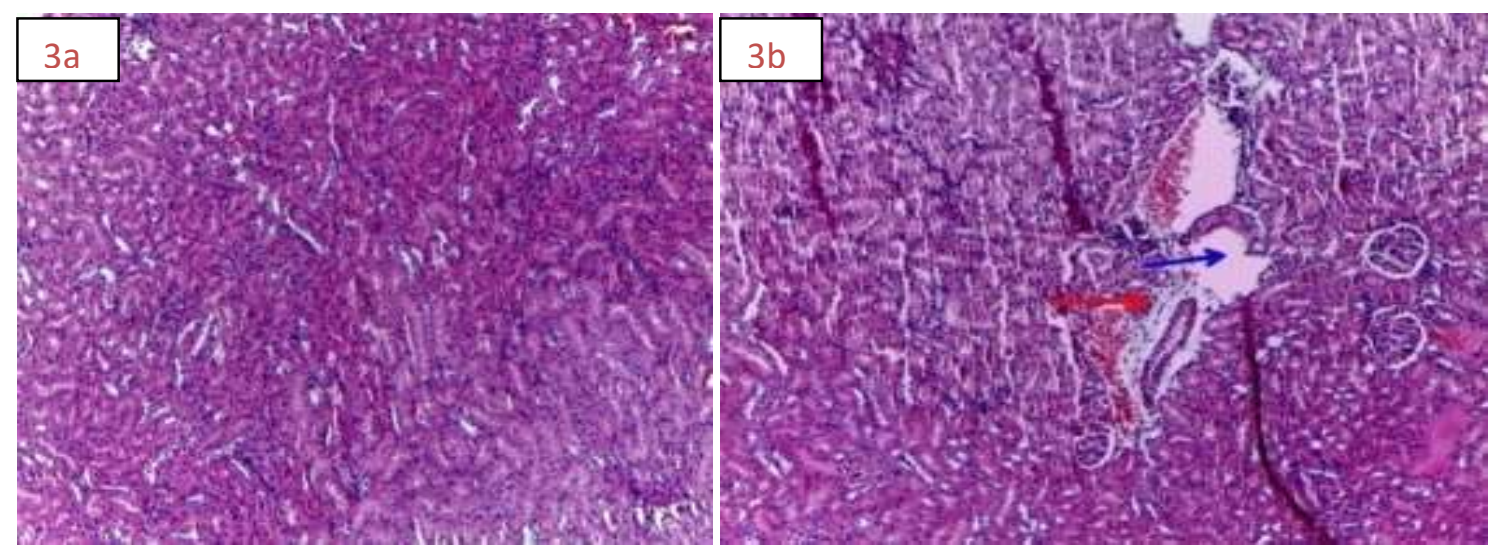

Plate 3a: Photomicrograph of wistar rat kidney tissues architecture without any visible lesion(H \& E mag x 100)

Plate 3b: Photomicrograph of wistar rat kidney tissues challenged with group III mosquito incense stick smoke showing areas of glomeruli distortion and group III (H \& E mag x 100)

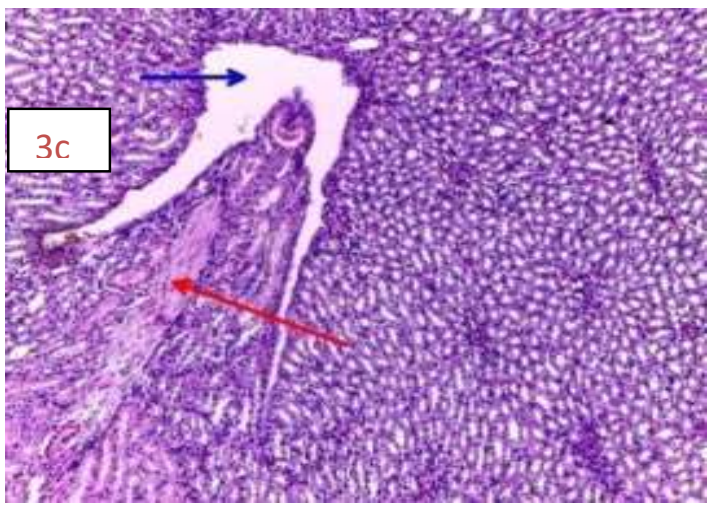

Plate 3c: Photomicrograph of wistar rat kidney tissues challenged with group IV mosquito incense stick smoke showing areas of mild haemorrhage and renal damage (H \& E mag x 100)

\section{DISCUSSION}

The present findings revealed that crucial liver biomarkers (AST, ALT and ALP) in the blood of all the experimental rats were altered significantly $(\mathrm{P}<0.05)$ when challenged with mosquito incense stick smoke. Increased activity of these hepatic enzymes when compared with control could be associated with hepatic damage as reported by Idowu et al. (2013) and Abdullah et al. (2017). This might be due to the effect of active ingredient in the mosquito incense sticks smoke allethrin or its by-product pyrethrum derived from pyrethroid metabolism on the membrane phospholipids of hepatocytes as obtained in group III incense sticks.

Allethrin has been reported to increase membrane fluidity in a living cell which allows passing through cellular enzymes within the extracellular matrix which facilitate transaminases activity in blood (Akunna et al., 2013 and Abdullah et al., 2017). Similar observations were reported by Karthikeyan et al. (2006) and Anvita et al. (2006) in mice, exposed to mosquito repellent mat vapour. In the present study, increase in the activity of ALT,
AST and ALP in the challenged groups insecticides sticks smoke especially group III, IV and V could also be attributed to hepatic injury, myocardial infarction and cardiovascular diseases as reported by Narendra et al. (2007). This is in tandem with the finding of Abubakar and Hassan (2007) who reported increased in liver enzymes (ALT, AST and ALP) due to exposure to different brands of mosquito coil (Swam, Rambo and Cork) smoke. Mossa et al. (2013) depicted that increased level of serum enzymes (ALT, AST and ALP) were due to exposure to pyrethriod-based insecticides and combination of different pyrethriod-based insecticides (Tetramethrin and Sumithrin).

The increased activity of liver enzymes in the experimental rats exposed to group II, III, IV and V might also be due to the presence of toxic chemicals in incense stick smoke that possibly interfere with catalytic interconversion of amino acids and $\alpha$ ketoacids by amino group in ALT as reported by Molina et al. (2005). During the study period, liver histology of experimental rats revealed hepatic disruption characterized by mild necrosis, 
degeneration of hepatocytes and cellular infiltration. The mild necrosis could be due to intracellular accumulations within the liver tissues as reported by Muhammad et al. (2014) and Abdullah et al. (2017). Histological alterations identified in the liver tissues of group II, III, IV and V mosquito incense sticks smoke inferred that it contains toxic compounds as reported by Sani and Ibrahim (2016). The hepatic cellular infiltrations examined in group III mosquito incense stick could be attributed to the inflammatory reaction in the liver cells as reported by Uthman et al. (2016).

Histological studies revealed mild lung damage evidenced by inflammatory cells disruption around alveolar septa, hyperplasia and degeneration of bronchiolar epithelial wall in challenged rats when exposed with group II, III, IV and V mosquito sticks smoke. Disruption of inflammatory cells around alveolar septa, hyperplasia might be due to inflammatory processes taking place as a result of irritation of pulmonary tissues by toxic chemicals from the incense sticks smoke as reported by Idowu et al. (2013), and Ghani and Shahbaz (2014). Similar observation was reported by Abubakar and Hassan (2007) in their work on toxicological effects of some mosquito coils brands in experimental rats. The body weakness experienced by the experimental rats may perhaps be due to toxic chemicals in mosquito sticks smoke.

Abdullah et al. (2017) reported the presence of carbon particles, heavy metals and aldehydes in the peripheral region of lung which leads to cellular injury and mucus membrane destruction in mice model exposed to mosquito coil. In the present findings, degeneration of bronchiolar epithelial wall might cause reduced oxygen carrying capacity of erythrocytes, leading to reduced cellular metabolism which may explain the body weakness experienced by the experimental rats as reported by Okine $e t$ al. (2004) and Yuonis et al. (2015). Epidemiological studies have shown that long-term exposureto mosquito coils smoke can induce asthma and persistent wheeze in children (Pankaj and Prahlad, 2004).

Damage to the kidney tissues with group III and IV mosquito sticks smoke could be due to decline in erythropoietin production which leads to high urea within kidney tissue and could lead to glumeruli distortion as reported by Nwanjo et al. (2005). This may perhaps revealed degeneration of fat as a result of alteration in metabolic activities within the kidney tissues. Similar observation was reported by Liu et al. (2003). Mild haemorrhage haemorrhage and renal damageexamined in the kidney tissues with group III mosquito sticks smoke may be due to Inflammatory response the kidney cells are exposed to or due to the presence of irritant in the insecticides incense stick such as pyrethrins and sulphates which have been reported to induce inflammatory response in kidney tissues (Abubakar and Hassan, 2006). Taiwo et al. (2008) reported severe multifocal congestion, interstitial mononuclear cellular infiltration and wide spread fibrosis in kidney tissues of exposed rats to mosquito coil.

\section{CONCLUSION AND RECOMMENDATIONS}

From the present finding it can be concluded that inhaling smoke from burning new brands of mosquito incense stick containing meperfluthrin, pyrethrum and allethrin for long term may not be safe as it revealed different pathological effect (biochemical and histopathological) in experimental rats. It is therefore recommended that further research should be carried out to assess the mechanism of toxicity, reversibility or irreversibility of the damage. Further study should also look into the effects of the new brands of mosquito incense stick smoke using other bioindicators of pollution.

\section{REFERENCES}

Abubakar, M and Hassan, L. (2007).Toxicological Effects of Some Mosquito Coils Brands In Experimental Rats. The Internet Journal of Toxicology, 4(1):1-4.

Abdullah, M. A., Ataur, M. R., Habibu, M. R., Hoque, K.M., Ferdousi, Z.,Mohammad; M, N and Abu, R. M. (2017) Biochemical and histological alterations induced by the smoke of allethrin based mosquito coil on mice model. BMC Clinical Pathology, 17(19): 1-8.

Akunna, G. G., Saalu, L. C., Ogunlade, B.,Ogunmodede, O. S. and Akingbade, A. M. (2013) Anti-fertility role of allethrin based mosquito coil on animal models. International Journal of Biology, Pharmacy and Allied Sciences, 2(2):192-207.

Anvita, S., Mithilesh,_K, S and Rayendra B. R. (2006). Ninety days toxicity and one generation reproduction study in rats exposed to allethrinbased mosquito stick J. Environ. Toxicol., $65: 45-48$.

Chen, S. C.,Wong, R. H.,Shiu, L. J.,Chiou, M. C. and Lee, H. (2008). Exposure to mosquito coil smoke may be a risk factor for lung cancer in Taiwan. Journal of Epidemiology, 18(1): 1925 .

El-Demerdash, F. M. (2011) Oxidative stress and hepatotoxicity induced by synthetic pyrethroids-organophosphate insecticides mixture in rat. $J$ Environ Sci Health $C$ Environ Carcinog Ecotoxicol Rev., 29:145-58.

Ezenwaji, N. E.,Yenagoa, B. and Nwaigwe, C. (2013). Changes in liver and plasma enzymes of Clariasgariepinus exposed to sublethal concentration of diesel. African Journal of Biotechnology, 12(4): 414-418.

Fetoui, H., Makni, M., Garoui, M. and Zeghal, N. (2010). Toxic effects of lambda-cyhalothrin, a synthetic pyrethroid pesticide, on the rat kidney: Involvement of oxidative stress and protective role of ascorbic acid. Exp. Toxicol. Pathol., 62: 593-599. 
Ghani, N. and Shahbaz, A. (2014). Toxic impacts of sub-chronic inhalation of mosquito coil smoke in rabbits International Research Journal of Environment Sciences, 3(5): 86-91.

Garba, S. H., Shehu, M. M. and Adelaiye, A. B. (2007). Histopathological and biochemical changes in the rats following exposure to a pyrethroid based mosquito coil. Journal of Applied Sciences Research, 39(12): 1788-1793.

Idowu, E.T.,Aimufua, O. J.,Ejovwoke, Y. O.,Akinsanya, B. and Otubanjo, O. A. (2013). Toxicological effects of prolonged and intense use of mosquito coil emission in rats and its implications on malaria control. Rev Biol Trop., 61:1463-73.

Idowu, E.T.,Omotayo, A.I. and Otubanjo, O.A. (2016). Evaluation of the toxicity of a mixture ofdichlorvos and formaldNationalehyde used for mosquito control in Nigeria. Niger. J. Parasitology, 37, 16-22.

Karthikeyan, S., Gobianand, K.,Pradeep, K.,Mohan, C. V. and Balasubramanian, M. P. (2006). Biochemical changes in serum, lung, heart and spleen tissues of mice exposed to sub-acute toxic inhalation of mosquito repellent mat vapour. J Environ Biol., 27:355-8.

Lawrance, C. E and Croft, A. M. (2004). Do mosquito sticks prevent malaria? A systematic review of traiils. J. Tranvel. Med., 11:92-96.

Liu, W. K.,Zhang, J.,Hashim, J. H.,Jalaludin, J.,Hashim, Z. and Goldstein, B. D. (2003). Mosquito coil emissions and health implications. Environ Health Perspect; 111(12): 1454 - 1460.

Mahmood, U.,Adebayo, B.,Ahmed-Sherif, I.,Abubakar, S. A.,Muhammad, M. M. and Haruna, D. U.(2018). Effect of exposure to mosquito coil smoke on short-term memory of adult wistar rats. Nig. J. Neurosci., 9(1):24-28.

Molina, R., Moreno, I., Pichardo, S., Jos, A., Moyano, R., Monterde, J.G. and Camean, A. (2005).Acid and alkaline phosphatase activities and pathological changes induced in Tilapia fish (Oreochromissp.) exposed subchronically to microcystins from toxic cyanobacterial blooms under laboratory conditions. Toxicology, 46: 725-735.

Mossa, A. T, Refaie, A. A.,Ramadan, A. and Bouajila, J. (2013) Amelioration of Prallethrininduced oxidative stress and hepatotoxicity in rat by the administration of Origanum majorana essential oil. Biomed Res Int., 1(1):1-11.

Muhammed, B. and Yakasai, U. A. (2017). Sub-acute toxicity study of some brands of air fresheners sold in kano on swiss albino rats (rattus norvegicus). International Journal of Advanced Academic Research, 3(5): 19-32.
Muhammad, A.S., Saidu, Y. and Bilbis, L.S. (2014). Effect of Dried Lake Salt (Kanwa) on Lipid Profile and Heart Histology of Female Albino Rats. Nig. Journal of Basic and Applied Sciences, 22(3 \& 4):73-78.

Nafiu, S. A; Hamisu, A and Zulaihat, H. A. (2020) Toxicological Assessment of Cyanobacterium (Microcystis aeruginosa) Extract on Histopathology and Biochemical Responses in Clarias gariepinus (Catfish) of Watari Reservoir, Kano, Nigeria. Dutse Journal of Pure and Applied Sciences, $6(2): 11-25$.

Narendra, M.,Bhatracharyulu, N. C.,Padmavathi, P. and Varadacharyulu, N. C. (2007). Prallethrin induced biochemical changes in erythrocyte membrane and red cell osmotic haemolysis in human volunteers. Chemosphere, 67(10): 65-71.

Nwanjo, H.U., Okafor, M. C and G.O. Oze, (2005) Changes in Biochemical parameters of kidney function in rats coadministered with chloroquine and aspirin. Journal of clinical sciences, 23: 10-12.

Ochei, J. and Kolhatkar, A. (2007).Medical Laboratory Science Theory and Practice.6th reprint. Tata McGraw-Hill New Delhi pp 918-923.

OECD (2011). Organization of Economic Co-operation and Development. Guidance Document on Acute Oral Toxicity.

Okine, L.K., Nyarko, A. K, Arma, G.E., Awumbila, K., Owusu, S., Set-soafia, S and Ofosuhene, M. (2004). Adverse effect of mosquito coil smoke on lungs, liver, creatinine and certain drugs metabolizing enzymes in male wistar albino rats. Ghana Medical Journal, 38(22): 4053-4056.

Pankaj, G. and Prahlad, G. (2004). Mosquito coil, allethrin poisoning in two brothers. Indian Journal of Pediatrics, 41: 1177-1178.

Sani, A. A and Ibrahim, A. A. (2016). Determination of toxic effects of commercial and local mosquito repellents in Oryctolagus cuniculus (New Zealand white). Sokoto Journal of Veterinary Sciences, 14(3): 54-57.

Taiwo, V.O., Nwagbara, N.P.,Suleiman, R., Angbashin, J.E. and Zarman, M.J. (2008). Clinicalsigns organ pathology in rats exposed to graded doses of pyrethroid-containing mosquito coil smoke and Aerosolized insecticidal sprays. African Journal of Biomedical Research, 11: 97-104.

Ugwu, O. O., Ibiam, A. U., Egwu, A. O., Ota-Umahi, G and Oga, O. (2016) The Effect of Pyrethroid-based Insecticides (Rambo and Raid mosquito coil) Smoke on Some Biochemical Indicesin Albino Rats and the Protective Effect of Aqueous Extract of Piper guineense.Middle-East Journal of Scientific Research, 24(2): 306-313. 
Uthman, G.S.,Miji, U. H.,Musa, H. A. and Musa, A. B. (2016). Exposure to incense of Meperfluthrin mosquito repellent-smoke causes Biochemical and Histopathological changes in Rabbits. Nigerian Journal of Pharmaceutical and Biomedical Research, 1(1): 68-74.

Yuonis, L.,Junfeng, Z.,Jamal, H.,Juliana, J.,Zailina, H. and Bernard, D. (2015). Mosquito coil emissions and health implications. Environmental Health Perspective, 111(1):14541460 . use, distribution, and reproduction in any medium, provided the original work is cited appropriately. 